Варбанець С. В., лікар-хірург серцево-судинний, завідувач відділення вроджених і набутих вад серця у підлітків та дорослих

Гур'єва О. С., канд. мед. наук, лікар-кардіолог

Козюра Г. М., лікар-інтерн

Ємець Г. І., лікар-хірург серцево-судинний

Ємець І. М., д-р мед. наук, професор, кардіохірург, директор

ДУ «Науково-практичний медичний центр дитячої кардіології та кардіохірургії МОЗ України», м. Київ, Україна

\title{
Неокуспідизація аортального клапана власним перикардом із використанням набору сайзерів і відповідних лекал - безпосередні результати
}

Резюме. У пацієнтів з аортальними вадами протезування аортального клапана (АК) біологічним протезом останнім часом швидко набуває популярності, незважаючи на недоліки, найголовнішими з яких є дегенерація протеза та зміна гемодинамічних властивостей кореня аорти. Як альтернатива протезуванню АК використання аутоперикарда для реконструкції АК може забезпечити сповільнення дегенерації нео-АК завдяки відсутності імунної реакції пацієнт-протез, а також оптимізацію гемодинаміки внаслідок збереження нормальної фізіології кореня аорти.

Мета - вивчити можливості проведення реконструкції АК за допомогою аутологічних тканин різними способами в дітей і дорослих та оцінити їх безпосередні результати.

Матеріали та методи. У період з 01.2015 по 30.06.2019 нами було виконано реконструкцію АК аутологічним перикардом у 50 пацієнтів з аортальними вадами, з яких $18 \%(n=9)$ становили діти віком від 6 до 18 років. Оперативні втручання виконували трьома способами: 1) реконструкція АК суцільним аутоперикардіальним клаптем $(\mathrm{n}=1)$; 2) реконструкція АК трьома окремими стулками $(\mathrm{n}=3)$; 3$)$ реконструкція АК окремими стулками з використанням розробленого набору вимірювачів та лекал (n = 46). Вимірювачі стулок АК багаторазового використання та відповідні лекала, за якими викроювали стулки АК, були розроблені на основі формул Гаспаряна В. та виготовлені ТОВ «Д. М. Мед-сервіс», м. Київ. Імплантацію стулок АК у 39 пацієнтів (84,78 \%) із 46 виконували за методикою, запропонованою Озакі Ш.

Результати

Випадків госпітальної летальності не спостерігалося. Добрі результати лікування мали $94 \%$ (n = 47) пацієнтів: АК був компетентний у $74 \%(n=37)$ прооперованих, у $12 \%(n=6)$ - аортальна недостатність (АН) була мінімальною, у 8 \% пацієнтів (n=4) - невеликою. Слід зазначити, що у 2 із 47 пацієнтів інтраопераційно було виявлено помірну АН, яку було успішно скориговано після повторного серцевого арешту.

У 3 (6 \%) хворих у ранньому післяопераційному періоді було виявлено наявність помірної або вираженої АН, яка потребувала реоперації протягом цієї госпіталізації. У двох випадках із трьох повторні втручання завершилися протезуванням, в одному - успішною корекцією.

Висновки. Операція неокуспідизації АК аутологічним перикардом є безпечною і демонструє добрі безпосередні результати. Використання набору вимірювачів і лекал, розробленого, базуючись на формулах Гаспаряна В. у поєднанні з хірургічною технікою, описаною Озакі Ш., роблять виконання операції більш швидким, спрощеним та стандартизованим.

Ключові слова: аортальний клапан, аортальна недостатність, реконструкція аортального клапана, неокуспідизація аортального клапана, аутологічний перикард.

Актуальність. Протезування аортального клапана (АК) біологічними протезами останнім часом швидко набуває популярності та витісняє використання механічних протезів у зв'язку з проблемами, пов'язаними
3 антикоагуляцією. Однак біологічні протези також мають певні недоліки. Найважливіший з них - це довговічність, яка залежить від швидкості дегенерації протеза та його кальцифікації [1-5]. Остаточний механізм 
кальцифікації та формування пануса в біологічних протезах невідомий, але доведено, що на це впливає імунологічна реакція між тканинами пацієнта та імплантованим клапаном і механічний стрес, який відбувається під час функціонування біопротеза [5-8].

Багато дослідників проводили пошук найбільш ефективної та відтворюваної методики реконструкції AK власними тканинами, яка б зберігала фізіологію та анатомію кореня аорти, близьку до нативної, та не залежала від анатомії та вираженості ураження тканин нативного клапана патологічним процесом [9, 10]. Важливим елементом вдалої реконструкції АК $є$ геометрія неостулок, від якої безпосередньо залежать якість та гемодинамічні властивості створеного клапана. Вивчення геометрії кореня аорти закордонними дослідниками транслювалося в розробку кількох методик розрахування параметрів стулок, які базуються на вимірюваннях діаметрів кільця АК, синотубулярного сполучення, висоти кореня аорти [11-13]. У цьому контексті оригінальною є експериментальна робота Гаспаряна В., в якій він запропонував формули залежності розміру стулки від міжкомісуральної відстані (МКВ), грунтуючись на природних математичних співвідношеннях між компонентами АК [14].

Використання аутологічного перикарда під час реконструкції АК шляхом нашивання стулок безпосередньо в позицію нативного аортального кільця має кілька переваг. По-перше, це відсутність імунної реакції між тканинами пацієнта та імплантованим клапаном, що потенційно може вплинути на швидкість його кальцинації [1-3, 15]. По-друге, безпосереднє нашивання аутоперикардіальних стулок до стінки кореня аорти замість нативного АК усуває необхідність використання стента, манжети або кільця, таким чином зберігаючи фізіологічну динаміку кореня аорти, який розширюється та скорочується під час систоли та діастоли [16-19]. У результаті вплив механічного стресу на стулки неоклапана зменшується, що є важливим механізмом пошкодження та кальцифікації стулок біологічних протезів [1-4, 19]. Також відсутність стента, кільця або манжети в аутоперикардіальному клапані забезпечує оптимальну гемодинаміку шляхом створення найбільшої площі відкриття неоклапана та практично невілює такий феномен, як «невідповідність пацієнт-протез». Опція транскатетерної імплантації АК в біологічний протез («клапан у клапан») 3 приводу його дегенерації все частіше розглядається як оптимальний варіант лікування, особливо в пацієнтів, у яких повторна відкрита хірургія асоціюється 3 високими ризиками. Аутоперикардіальні клапани теоретично можуть мати значні переваги в контексті майбутньої транскатетерної процедури через відсутність стента або манжети та можливості інтервенційної імплантації клапана більшого розміру.
Метою нашого дослідження було оцінити можливість виконання неокуспідизації АК аутоперикардіальними стулками, базуючись на математичних розрахунках Гаспаряна В., та дослідити безпосередні результати оперативних втручань.

Матеріали та методи. У період з 01.2015 по 30.06.2019 нами було виконано реконструкцію АК аутологічним перикардом у 50 пацієнтів 3 аортальними вадами, 3 яких $18 \%(\mathrm{n}=9)$ становили діти віком від 6 до 18 років. Концепція нашої роботи базувалася на математичних розрахунках, описаних i запропонованих Гаспаряном В. і співавторами в 2000 році [14]. Грунтуючись на природних математичних співвідношеннях між компонентами аортального клапана, Гаспарян запропонував формули залежності розмірів стулки від МКВ. Форма стулки АК визначається таким чином:

$$
\begin{aligned}
& \mathrm{L}=1,2 \times 1, \\
& \mathrm{H}=0,86 \times 1, \\
& \mathrm{~K}=0,266 \times 1, \\
& \mathrm{R}=0,6 \times 1,
\end{aligned}
$$

де $\mathrm{L}$ - вільний край стулки аортального клапана, H - висота стулки, K - висота комісури, $\mathrm{R}$ - радіус стулки, 1 - міжкомісуральна відстань.

Упровадження методики неокуспідизації в клініці НПМЦДКК мало еволюційний шлях, зокрема іiї проводили трьома різними способами, які відрізнялися за методикою викроювання та імплантації стулок.

Спосіб № 1: реконструкція АK суцільним аутоперикардіальним клаптем

Після виконання стандартної серединної стернотомії брали аутоперикард та обробляли його в $0,6 \%$ розчині глутаральдегіду впродовж 10 хв з наступним промиванням у трьох окремих посудинах з нормальним ізотонічним розчином натрію хлориду. Під час підготовки аутоперикардіальної латки підключали апарат штучного кровообігу шляхом канюляції аорти та обох порожнистих вен. Після досягнення серцевого арешту та поперечної аортотомії оцінювали та видаляли нативний АK. Наступним етапом, за допомогою мірної нитки, окремо визначали розмір кожної із трьох МКВ: лівої, правої та некоронарної стулок. Користуючись математичними розрахунками, описаними вище, на стерильному листі паперу викроювали три стулки у формі суцільного клаптя, згідно з оригінальною методикою, описаною Гаспаряном В. Лист паперу накладали на аутоперикард та 3 останнього по трафарету вирізали три неостулки у вигляді суцільного клаптя з урахуванням додаткової відстані, необхідної для шва. Викроєний таким чином аутоперикардіальний клапан імплантували в позицію нативного аортального кільця безперервним швом.

За цією методикою прооперовано одного пацієнта.

Спосіб № 2: реконструкція АК трьома окремими стулками

На відміну від першого цей спосіб був спрощений за рахунок викроювання та вирізання трьох окремих 

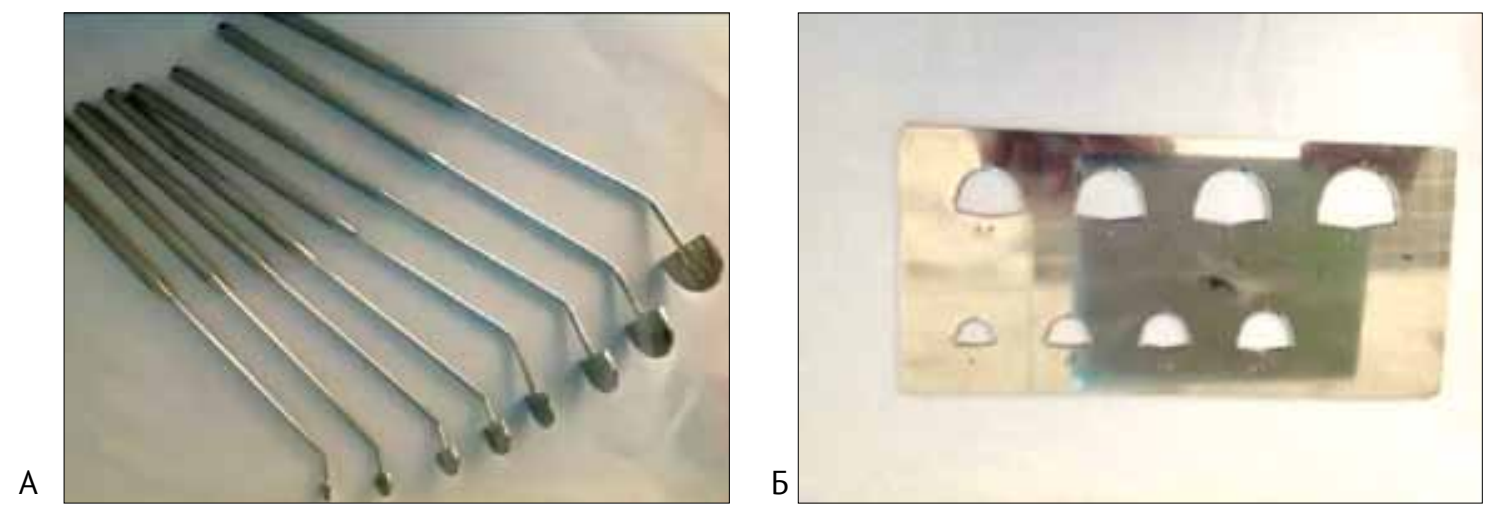

Рисунок 1. Комплект вимірювачів (сайзерів) (А) та лекала (Б)

стулок. Підхід до розрахунку параметрів стулок не відрізнявся від попереднього. Імплантація аутоперикардіального клапана в цьому випадку виявилася значно простішою та прогнозованою для хірурга, більшою мірою завдяки зручності маніпуляції та нашивання кожної стулки по черзі на відміну від імплантації суцільного тристулкового клаптя. За цим способом було прооперовано три пацієнти.

Спосіб № 3: реконструкція АК окремими стулками 3 використанням розробленого набору вимірювачів та лекал

Для оптимізації вимірювання та створення стулок AK нами розроблено набір вимірювачів і відповідних лекал, конфігурація яких базувалася на вищезазначених розрахунках Гаспаряна В. (рисунок 1). Інструменти були виготовлені ТОВ «Д. М. Мед-сервіс», м. Київ.

Після виконання стандартної серединної стернотомії брали аутоперикард та обробляли його в $0,6 \%$ розчині глутаральдегіду впродовж 10 хв 3 наступним промиванням у трьох окремих ємностях з нормальним ізотонічним розчином натрію хлориду. Під час підготовки аутоперикардіальної латки виконували підключення апарата штучного кровообігу шляхом канюляції аорти та вушка правого передсердя або обох порожнистих вен залежно від необхідності в додаткових процедурах. Після досягнення серцевого арешту та поперечної аортотомії, оцінювали й видаляли АК з декальцинацією кільця та прилеглих структур за потреби. Наступним етапом окремо визначали розмір кожної із трьох міжкомісуральних відстаней: лівої, правої та некоронарної стулок. За наявності двостулкового АК, після його видалення, ми йшли шляхом створення тристулкового неоклапана. Для цього маркером відмічали три неокомісури, намагаючись зробити їх на максимально однаковій відстані одна від одної і потім визначали розмір трьох сформованих МКВ. Отримавши три розміри вимірювачів для кожної окремої стулки, на відповідному номері лекала та аутоперикардіальній латці викреслювали і вирізали три неостулки АК. Під час підготовки аутоперикардіальних стулок за потреби виконували супутні процедури: нашивання дистальних коронарних анастомозів, пластику мітрального клапана (МK), пластику тристулкового клапана (ТК), корекцію аневризми висхідної аорти, процедуру радіочастотної абляції, резекцію вушка лівого передсердя. В останню чергу в позицію АК імплантували аутоперикардіальний аортальний неоклапан.

3 використанням набору вимірювачів та лекал було виконано 46 втручань. Слід зазначити, що у 39 із 46 випадків ми використовували оригінальну методику нашивання стулок, описану Озакі Ш. [20].

Результати корекції аортальної вади в усіх випадках оцінювали інтраопераційно за допомогою трансезофагеального ехокардіографічного дослідження (ЕхоКГ) та трансторакальної ЕхоКГ протягом післяопераційного періоду відповідно до чинних рекомендацій [21-24].

Статистичну обробку даних проводили за допомогою пакета програм Microsoft Excel та SPSS 19.0.

Результати та обговорення. Медіана віку 50 прооперованих пацієнтів з приводу аортальної вади сягала 61,42 року (від 6,44 до 81,64). Переважну більшість становили пацієнти дорослого віку $82 \%(\mathrm{n}=41), 66 \%$ були чоловіки $(\mathrm{n}=33)$.

Характеристики анатомії вади наведені в таблиці 1. Серед прооперованих переважали пацієнти із аортальним стенозом (АС) (72\%). Тристулкова анатомія AK мала місце у $70 \%$ випадків. Слід зазначити, що в пацієнтів з двостулковою анатомією АК $(\mathrm{n}=15)$, у більшості випадків $(66,66 \%, \mathrm{n}=10)$ було діагностовано моностулковий клапан (тип II за класифікацією Сіверса [15]). 80 \% хворих із моностулковим АК були чоловічої статі. Цікавим є факт, що у 9 з 10 пацієнтів $з$ моностулковим АК були наявні рафе між лівою і правою $(\mathrm{L} / \mathrm{R})$ та правою і некоронарною $(\mathrm{R} / \mathrm{N})$ стулками. В одному випадку зрощеними були ліва й права $(\mathrm{L} / \mathrm{R})$ та ліва і некоронарна (L/N) стулки. Усі пацієнти із двостулковим AK I типу за Сіверсом були чоловічої статі $(\mathrm{n}=5)$ та у 3 з них було наявне рафе між лівою та пра- 


\section{Таблиця 1}

Ехокардіографічні характеристики вади серия, анатомії кореня аорти та внутрішньосерцевої гемодинаміки $(n=50)$

\begin{tabular}{|c|c|}
\hline Показник & $n=50 \%$ \\
\hline АН виражена (ізольована або переважаюча) & 14,00 \\
\hline АC (ізольований або переважаючий) & 72,00 \\
\hline $\begin{array}{l}\text { Комбінована виражена аортальна вада без } \\
\text { переваги }\end{array}$ & 6,00 \\
\hline Помірна аортальна вада & 8,00 \\
\hline Тристулковий АК & 70 \\
\hline Двостулковий АК, I тип & 10 \\
\hline Двостулковий АК, II тип & 20 \\
\hline Показник & $M \pm S D$ \\
\hline АШС індекс, мм/м² & $12,83 \pm 2,66$ \\
\hline Синус Вальсальви, індекс, мм/м² & $17,34 \pm 2,81$ \\
\hline СТС, індекс, мм/м² & $14,60 \pm 3,29$ \\
\hline Висхідна аорта, індекс, мм/м² & $19,15 \pm 4,31$ \\
\hline$\Delta \mathrm{p}$ АК макс., мм рт. ст. & $77,70 \pm 34,85$ \\
\hline$\Delta$ р АК сер., мм рт. ст. & $46,10 \pm 23,34$ \\
\hline ФВ ЛШ, \% & $58,66 \pm 12,03$ \\
\hline КДІ, мл/м² & $62,16 \pm 27,05$ \\
\hline
\end{tabular}

Примітка. АН - аортальна недостатність; АШС - аорто-шлуночкове сполучення (показник індексований за площею поверхні тіла); СТС - синотубулярне сполучення (показник індексований за площею поверхні тіла); ФВ ЛШ - фракція викиду лівого шлуночка; КДІ - кінцево-діастолічний індекс.

вою коронарними стулками (L/R). У двох інших пацієнтів, відповідно, зрощеними були некоронарна і ліва $(\mathrm{L} / \mathrm{N})(\mathrm{n}=1)$ та некоронарна і права $(\mathrm{R} / \mathrm{N})(\mathrm{n}=1)$.

У всіх пацієнтів операції із штучним кровообігом не проводили раніше. Двоє дітей мали в анамнезі попередні втручання: резекцію коарктації аорти $(\mathrm{n}=1)$ та балонну дилатацію стенозу АК $(\mathrm{n}=1)$.

У п’яти пацієнтів виявлено дилатацію висхідної аорти. В однієї дитини виконано пластику висхідної аорти (таблиця 2). У чотирьох дорослих пацієнтів розміри висхідної аорти варіювали в межах 41-45 мм, що не було показанням для проведення хірургічної корекції.

Найчастішою супутньою патологією в дорослих були ішемічна хвороба серця (IXC) (38 \%) та мітральна недостатність (МН) помірного або вираженого ступеня (14\%). 3 цього приводу симультанно виконано 17 операцій аорто-коронарного шунтування (АКШ) та чотири пластики МК.

Фібриляція передсердь була наявною у $12,19 \%$ дорослих пацієнтів $(n=5)$, що було показанням до резекції вушка лівого передсердя у чотирьох хворих. Радіочастотну абляцію монополярним електродом (СохMaze IV, left atrial set) виконували в одному випадку.

\section{Таблиця 2}

Характеристика пацієнтів за наявністю супутньої патології та проведеними хірургічними втручаннями

\begin{tabular}{lc} 
Показники & $\mathbf{n}=\mathbf{5 0 ,} \%$ (хв.) \\
\hline Супутня патологія & $10(5)$ \\
\hline Дилатація кореня або висхідної аорти & $36(18)$ \\
\hline ІХС & $14(7)$ \\
\hline $\begin{array}{l}\text { Недостатність МК помірного або більшого } \\
\text { Недостатність ТК вираженого ступеня }\end{array}$ \\
\hline Фібриляція передсердь & $4(2)$ \\
\hline Інфекційний ендокардит & $10(5)$ \\
\hline Попередні втручання & $2(1)$ \\
\hline Корекція коарктації аорти, \% & $2(1)$ \\
\hline Балонна дилатація АК, \% & $2(1)$ \\
\hline Супутні хірургічні втручання & \\
\hline АКШ & $2(17)$ \\
З яких з пластикою ТК & $8(4)$ \\
\hline Пластика МК & $2(1)$ \\
\hline Радіочастотна абляція & $2(1)$ \\
\hline Пластика висхідної аорти &
\end{tabular}

Слід зазначити, що в середньому час штучного кровообігу та перетискання аорти становив 184,39 (від 90 до 321 хв) та 134,71 (від 46 до 213 хв) відповідно. У хворих, яким було виконано ізольовану неокуспідизацію AK $(\mathrm{n}=27)$, час штучного кровообігу був достовірно меншим порівняно із таким у пацієнтів із супутніми втручаннями $(\mathrm{n}=23)$ і досягав 158,46 \pm 6,63 хв проти $213,70 \pm 8,50$ хв. Час перетискання аорти також закономірно відрізнявся залежно від необхідності в супутньому втручанні: $111,73 \pm 4,77$ хв проти $160,70 \pm 5,80$ хв відповідно.

Для вимірювання лівої коронарної стулки використовували вимірювачі номерами від 16 до 26, що відповідало розмірам МКВ від 19,2 до 31,2 мм. Найчастіше використовувалися вимірювачі № 22 $(\mathrm{n}=12)$ та $24(\mathrm{n}=9)$. Для вимірювання правої коронарної стулки використовували вимірювачі номерами від 14 до 26, що відповідало розмірам МКВ від 16,8 до 31,2 мм. Найчастіше використовували вимірювачі № $20(\mathrm{n}=9) ; 22(\mathrm{n}=13)$ та $24(\mathrm{n}=11)$. Для вимірювання некоронарної стулки використовували вимірювачі номерами від 14 до 28, що відповідало розмірам МКВ від 14,4 до 33,6 мм. Найчастіше використовували вимірювачі № $20(\mathrm{n}=9)$; $22(\mathrm{n}=12)$ та $24(\mathrm{n}=8)$. Міжкомісуральна відстань, виміряна за допомогою комплекту інструментів, добре корелювала із даними інтраопераційної трансезофагеальної ЕхоКГ нативного клапана, що потенційно надає можливість у подальшому викроювати неостулки, базуючись на даних трансезофагеаль- 
ної ЕхоКГ до основного етапу операції, тим самим зменшуючи час серцевого арешту.

Безпосередні результати неокуспідизації АК, проаналізовані на час виписування пацієнтів зі стаціонару, свідчили про ефективність і безпечність методу. Випадків госпітальної летальності не спостерігалося. Добрі результати лікування мали $94 \%(\mathrm{n}=47)$ пацієнтів: АК був компетентний у $74 \%(\mathrm{n}=37)$ прооперованих, у $12 \%(\mathrm{n}=6)-\mathrm{AH}$ була мінімальною, у $8 \%$ пацієнтів $(\mathrm{n}=4)$ - невеликою. Слід зазначити, що у 2 з 47 пацієнтів інтраопераційно було виявлено помірну АН, яку було успішно скориговано після повторного серцевого арешту. У жодного із 47 пацієнтів не зареєстровано AC після операції. Закономірно в загальній групі пацієнтів $(\mathrm{n}=50)$ спостерігалося достовірне зниження середнього та максимального градієнтів тиску на AK, які після операції становили відповідно 7,87 $\pm 3,90$ та $15,98 \pm 7,27$. Значущого приросту скоротливої функції та ознак ремоделювання лівого шлуночка на час виписування зі стаціонару не було.

У 3 (6 \%) хворих у ранньому післяопераційному періоді було виявлено наявність помірної або вираженої АН, яка потребувала реоперації в ту саму госпіталізацію. У дорослого пацієнта (21,8 року) АК був двостулковим (type I R/N), у двох дітей (16,9 та 14,5 року) була наявна комбінована вада моностулкового АK (L/R; R/N i L/R; L/N відповідно). У двох випадках невдалої корекції неокуспідизацію проводили другим способом (без використання вимірювачів) та в одному випадку - третім способом (з використанням вимірювачів), без дотримання протоколу імплантації стулок Озакі Ш. У всіх трьох випадках розвиток АН помірного або вираженого ступеня було діагностовано при трансторакальній ЕхоКГ. В одного розвиток АН був спричинений відривом лівої неостулки та успішно скоригований. У двох інших випадках найвірогідніше ступінь АН був недооцінений інтрапераційно, про що свідчила відсутність структурних дефектів нео-АК при ревізії. Імовірними механізмами розвитку були різна висота неокомісур АK та/або некоректне вимірювання стулок. Слід зазначити, що вимірювання розмірів стулок для створення тристулкової анатомії в пацієнтів із моно- та двостулковим АК має технічні складнощі. У зв'язку з цим деякі автори уникають проведення неокуспідизації в пацієнтів з вадами моно- та двохстулкового клапана [25].

Результати неокуспідизації АК залежать значною мірою від досвіду хірурга та використаної методики. Наприклад, добрих клінічних безпосередніх і задовільних віддалених результатів неокуспідизації АК, зіставних з такими при протезуванні біологічним протезом, було досягнуто ще Дюраном та співавторами в 1995 році [9]. Також окремої уваги заслуговують роботи Дрейфуса та колег, які в 2011 році представили успішні результати повної заміни АК з використанням аутопе- рикарда в 11 пацієнтів [10]. Але методики, які застосовувалися авторами, не знайшли значного поширення, найвірогідніше через технічні труднощі, пов’язані з викроюванням та імплантацією неостулок у вигляді єдиного клаптя аутоперикарда.

Значного успіху в цьому напрямку досягла група дослідників на чолі з Озакі Ш., який для конструювання окремих неостулок АК розробив спеціальний набір інструментів, що суттєво полегшило і прискорило створення аутоперикардіальних стулок для неокуспідизації AK [20]. У нашій роботі ми користувалися подібними принципами (створення окремих стулок та застосування зручних інструментів). Однак основною відмінністю нашого дослідження є створення вимірювачів і відповідних лекал, базуючись на експериментальних дослідженнях Гаспаряна В.

Таким чином, добрі безпосередні результати реконструкції АК аутологічним перикардом, отримані в нашому дослідженні, та успішні віддалені результати інших хірургічних центрів, дозволяють припустити, що неокуспідизація АК може бути рівнозначною, а іноді і більш привабливою альтернативою біологічному протезу.

Висновки. Операція неокуспідизації АК аутологічним перикардом $є$ безпечною і демонструє добрі безпосередні результати. Використання набору вимірювачів і лекал, розробленого, базуючись на формулах Гаспаряна В. в поєднанні з хірургічною технікою, описаною Озакі Ш., роблять виконання операції більш швидким, спрощеним та стандартизованим.

Подяка. Лікарям «Науково-практичного медичного центру дитячої кардіології та кардіохірургії МО3 України Балтаєвій Г. Ю., Булі М. С., Дякун М. Є., Маршалок У. М., Фурману М. М., Цвику А. С., Чернецькому $\mathrm{E}$. O.

\section{Список використаних джерел References}

1. Aupart MR, Sirinelli AL, Diemont FF, Meurisse YA, Dreyfus XB, Marchand MA. The last generation of pericardial valves in the aortic position: ten-year follow-up in 589 patients. Ann Thorac Surg. 1996;61:615-20. https:// doi.org/10.1016/0003-4975(95)00953-1

2. Banbury MK, Cosgrove DM, Lytle BW, Smedira NG, Sabik JF, Saunders CR. Long-term results of the CarpentierEdwards pericardial aortic valve: a 12-year follow-up. Ann Thorac Surg. 1998;66:S73-6.

3. Grabenwoger M, Fitzal F, Gross C, Hutschala D, Bock P, Brucke $\mathrm{P}$, et al. Different modes of degeneration in autologous and heterologous heart valve prostheses. J Heart Valve Dis. 2000;9:104-9.

4. Mohammadi S, Baillot R, Voisine P, Mathieu P, Dagenais F. Structural deterioration of the Freestyle aortic valve: mode of presentation and mechanisms. $\mathbf{J}$ Thorac Cardiovasc Surg. 2006;132:401-6. https://doi.org/10.1016/j. jtcvs.2006.03.056 
5. Butany J, Zhou T, Leong SW, Cunningham KS, Thangaroopan M, Jeggatheeswaran A, et al. Inflammation and infection in nine surgically explanted Medtronic Freestyle stentless aortic valves. Cardiovasc Pathol. 2007;16(5):25867. https://doi.org/10.1016/j.carpath.2007.01.009

6. Human P, Zilla P. The possible role of immune responses in bioprosthetic heart valve failure. J Heart Valve Dis. 2001;10:460-6.

7. Konakci K, Bohle B, Blumer R, Hoetzenecker W, Roth G, Moser B, et al. Alpha-Gal on bioprostheses: xenograft immune response in cardiac surgery. Eur $\mathbf{J}$ Clin Invest. 2005;35:17-23. https://doi.org/10.1111/j.13652362.2005.01441.x

8. Siddiqui RF, Abraham JR, Butany J. Bioprosthetic heart valves: modes of failure. Histopathology. 2009;55:135-44. https://doi.org/10.1111/j.1365-2559.2008.03190.x

9. Al Halees Z, Al Shahid M, Al Sanei A, Sallehuddin A, Duran C. Up to 16 years follow-up of aortic valve reconstruction with pericardium: a stentless readily available cheap valve? Eur J Cardiothorac Surg. 2005 Aug;28(2):200-5; discussion 205. https://doi.org/10.1016/j.ejcts.2005.04.041

10. Chan KM, Rahman-Haley S, Mittal TK, Gavino JA, Dreyfus GD. Truly stentless autologous pericardial aortic valve replacement: An alternative to standard aortic valve replacement. J Thorac Cardiovasc Surg. 2011 Jan;141(1):276-83. https://doi.org/10.1016/j. jtcvs.2010.09.038

11. Mercer JL, Benedicty M, Bahnson HT. The geometry and construction of the aortic leaflet. J Thorac Cardiovasc Surg. 1973;65:511-8.

12. Swanson M, Clark RE. Dimensions and geometric relationships of the human aortic valve as a function of pressure. Circ Res. 1974;35:871-82. https://doi. org/10.1161/01.res.35.6.871

13. Silver MA, Roberts WC. Detailed anatomy of the normally functioning aortic valve in hearts of normal and increased weight. Am J Cardiol. 1985;55:454-61. https://doi. org/10.1016/0002-9149(85)90393-5

14. Gasparyan VC. Method of determination of aortic valve parameters for its reconstruction with autopericardium: An experimental study. J Thorac Cardiovasc Surg. 2000;119:386-7.

15. Duran CMG, Gometza B, Kumar N, Gallo R, MartinDuran R. Aortic valve replacement with freehand autologous pericardium. J Thorac Cardiovasc Surg. 1995;110:511-6. https://doi.org/10.1016/S0022-5223(95)70248-2

16. Cheng A, Dagum P, Miller DG. Aortic root dynamics and surgery: from craft to science. Philos Trans R Soc Lond B Biol Sci. 2007;362:1407-19. https://doi.org/10.1098/ rstb.2007.2124
17. Rodriguez F, Green G, Dagum P, Nistral JF, Harrington $\mathrm{KB}$, Daughters GT, et al. Left ventricular volume shifts and aortic root expansion during isovolumic contraction. $\mathbf{J}$ Heart Valve Dis. 2006;15:465-73.

18. Lansac E, Lim HS, Shomura Y, Lim KH, Rice NT, Goetz W, et al. A four-dimensional study of the aortic root dynamics. Eur J Cardiothorac Surg. 2002 Oct;22(4):497503. https://doi.org/10.1016/s1010-7940(02)00405-0

19. Thubrikar MJ, Deck JD, Aouad J, Nolan SP. Role of mechanical stress in calcification of aortic bioprosthetic valves. J Thorac Cardiovasc Surg. 1983;86:115-25.

20. Ozaki S, Kawase I, Yamashita H, Uchida S, Takatoh M, Kiyohara N. Midterm outcomes after aortic valve neocuspidization with glutaraldehyde-treated autologous pericardium. J Thorac Cardiovasc Surg. 2018 Jun;155(6):2379-87. https://doi.org/10.1016/j. jtcvs.2018.01.087

21. Lopez L, Colan SD, Frommelt PC, Ensing GJ, Kendall K, Younoszai AK, Lai WW, Geva T. Recommendations for Quantification Methods During the Performance of a Pediatric Echocardiogram: A Report From the Pediatric Measurements Writing Group of the American Society of Echocardiography Pediatric and Congenital Heart Disease Council. J Am Soc Echocardiogr. 2010 May;23(5):465-95; quiz 576-7. https://doi.org/10.1016/j.echo.2010.03.019

22. Vahanian A, Baumgartner H, Bax J, Butchart E, Dion R, Filippatos G, et al. Guidelines on the management of valvular heart disease: The Task Force on the Management of Valvular Heart Disease of the European Society of Cardiology. Eur Heart J. 2007 Jan;28(2):230-68. https:// doi.org/10.1093/eurheartj/ehl428

23. Joint Task Force on the Management of Valvular Heart Disease of the European Society of Cardiology (ESC); European Association for Cardio-Thoracic Surgery (EACTS), Vahanian A, Alfieri O, Andreotti F, Antunes MJ, et al. Guidelines on the management of valvular heart disease (version 2012). European Heart Journal. 2012;33:2451-96. https://doi.org/10.1093/eurheartj/ehs109

24. Baumgartner H, Falk V, Bax JJ, De Bonis M, Hamm C, Holm PJ, et al. 2017 ESC/EACTS Guidelines for the management of valvular heart disease. European Heart Journal. 2017;38:2739-91. https://doi.org/10.1093/ eurheartj/ehx391

25. Hassanein M, Zayed A. Early Experience in Aortic Valve Reconstruction with Autologous Pericardium for Aortic Valve Insufficiency. J Cardiovascular Thoracic Surgery. 2017;2(3):1-4. https://doi.org/10.15226/2573$864 \mathrm{X} / 2 / 3 / 00118$ 


\title{
Aortic Valve Neocuspidization with Autologous Pericardium Using Sizers and Templates: Short-Term Outcomes
}

\author{
Varbanets S. V., Gurjeva O. S., Kosiura G. M., Yemets G. I., Yemets I. M. \\ Ukrainian Children's Cardiac Center, Kyiv, Ukraine
}

\begin{abstract}
Background. Despite certain disadvantages of aortic valve replacement (AVR) using biological prosthesis, e.g. valve degeneration and non-optimal haemodynamic properties, it's becoming more popular in patients of different age groups. The use of autologous pericardium for aortic valve (AV) reconstruction could be a reasonable alternative to AVR and may provide slower degeneration of neo-AV due to the absence of patient-prosthesis immune reaction as well as optimization of haemodymanics resulting from preservation of normal physiology of aortic root.

Objective. To study the opportunities of AV reconstruction in children and in adults with autologous tissues using different techniques and to evaluate short-term outcomes of surgical treatment.

Methods. From 01/2015 to 06/2019 we have performed AV reconstruction with autologous pericardium in 50 patients with AV disease. Of these, $18 \%(n=9)$ were children from 6 to 18 years of age. Three methods of AV reconstruction were applied: 1) AV reconstruction with solid autopericardial patch $(\mathrm{n}=1) ; 2)$ AV reconstruction with separate autopericardial leaflets without use of sizers $(n=3) ; 3)$ AV reconstruction with separate autopericardial leaflets using sizers and templates $(\mathrm{n}=46)$. Reusable resterilizable sizers and corresponding templates were constructed according to the formulas proposed by W. Gasparyan and manufactured as a sample set by Med-Service Ltd, Kyiv, Ukraine. In 39 patients (84.78\%) we have used Ozaki leaflet implantation technique.

Results. There were no fatal cases during the observation period. In $94 \%$ of patients $(\mathrm{n}=47)$, good outcomes of AV reconstruction were observed: $\mathrm{AV}$ was competent in $74 \%(\mathrm{n}=37)$ of patients, aortic regurgitation $(\mathrm{AR})$ was trivial in $12 \%$ $(n=6)$ of cases, and $8 \%(n=4)$ of patients had mild AR on discharge. It should be noted that in 2 of 47 patients moderate AR was diagnosed and successfully corrected intraoperatively after reclamping of aorta.

Three patients $(6 \%)$ with bicuspid AV anatomy were diagnosed with moderate or severe AR which required reoperation during the same hospitalization. In one case AR was corrected by means of repeated reconstruction. In two other cases AV valve was replaced with mechanical prosthesis.

Conclusions. AV neocuspidization with autologous pericardium is a safe procedure which demonstrates good short-term outcomes. The use of originally produced set of sizers and templates developed according to W. Gasparyan's formula in combination with Ozaki technique of leaflets implantation simplify the procedure, are time-saving and improve reproducibility of the operation performed.
\end{abstract}

Keywords: aortic valve, aortic regurgitation, aortic valve reconstruction, autologous pericardium.

Стаття надійшла в редакцію 31.07.2019 р. 